\title{
Undoing a Model System: A new federal custody notification service
}

\section{Dr Eugene Schofield-Georgeson (Lecturer - UTS Law School)}

\begin{abstract}
The custody notification service (CNS) is a legislative scheme to prevent Aboriginal deaths in custody. This article discusses proposed changes to the federal CNS, currently before the federal Parliament in late 2017. It argues that the changes are inadequate, when compared with CNS models in other Australian jurisdictions, primarily because the laws deprive Aboriginal people of important fair trial and custody rights. This paper concludes by listing a range of legislative solutions proposed by Aboriginal organisations and legal representatives.
\end{abstract}

\section{Undoing a Model System: A new federal custody notification service}

In August 1987, an Aboriginal man, Lloyd James Boney, was found dead in the police lock-up at Brewarrina in north western New South Wales. He had been hanged by his football socks, 90 minutes after being arrested. Witnesses said that, at the time of arrest, Boney was paralytically drunk and incapable of the complex task of fashioning a makeshift noose from his socks. No charges were laid against police. ${ }^{i}$ During the 1980s, reporting of similar Aboriginal deaths in police custody became commonplace. After much campaigning by Aboriginal activists, the Hawke Government established the Royal Commission into Aboriginal Deaths in Custody (RCIADIC), which delivered findings in 1991. Few of its 339 recommendations were implemented. Some recommendations, however, relating to the establishment of a Custody Notification Service (CNS), were eventually enacted in various Australian jurisdictions. 
The CNS is a hotline between police and Aboriginal Legal Assistance Organisations (ALAOs) to monitor and observe the treatment of Aboriginal people in police custody. When an Aboriginal person is taken into custody, the CNS requires police to call an ALAO, and allow the detained person to speak to a lawyer or 'prisoners friend'. Its implementation corresponded with a dramatic decline in Aboriginal deaths in custody. In NSW, where the scheme has been assisted by some of the most comprehensive CNS law in the country, rates of Aboriginal deaths fell from 18 per year in 1988 (in NSW alone) to zero, for over ten consecutive years. ${ }^{\text {ii }}$ Other State and Territory CNS jurisdictions have also seen reductions in Aboriginal deaths in custody. Despite their apparent success, CNS programs have been consistently threatened by funding cuts and, more recently, legislative intervention, designed to 'streamline' the custody process in the interests of police.

This article critically reviews the latest legislative intervention by the Australian Federal Coalition Government to amend the CNS at the level of federal procedural criminal law. It documents how, in formulating this proposed law, the Government has ignored the needs of important stakeholders - Aboriginal people, as well as ALAOs, their legal representatives. Argued here is that the proposed laws provide for a CNS 'lite', a scheme that seeks merely to reduce, rather than end, Aboriginal deaths in police custody while stripping Aboriginal people of vital fair trial and custody rights. In making this claim, the article first explores the impact of the proposed amendments on custody rights for Aboriginal people and explains how the legislation provides for a one-sided procedural scheme weighted in the interests of police. Next, this article considers a similar, but preferable, CNS scheme in New South Wales that is more sensitive to the needs of Aboriginal people and has seen comparatively fewer deaths in custody A final section examines the perspectives of ALAOs and other interested stakeholders in 
respect to the proposed laws which inform a list of concluding observations about these prospective laws and an array of possible legislative solutions.

Custody notification services serve a dual purpose in administering legal oversight of police to prevent deaths in custody, while also ensuring that detained Aboriginal people are advised their legal rights - most importantly, the right to silence and privilege against self-incrimination. These rights are important, specifically for Aboriginal people, because their exercise sometimes prevents police from obtaining confessional evidence (unfairly or otherwise). ${ }^{\mathrm{iii}}$ By relying on these rights, Aboriginal people can be diverted from the cycle of conviction, imprisonment, recidivism and the structural injustice associated with their overrepresentation in Australian prisons The CNS also facilitates the right to legal representation and access to a prisoner's friend (recognised as an important custody right for Aboriginal people, since the formulation of the Anunga Rules in the $1970 \mathrm{~s}^{\mathrm{iv}}$ and since codified by the NSW legislation, discussed below ${ }^{v}$ ). These rights are almost always accorded to Aboriginal people in custody, as soon as they make contact with an ALAO through a CNS scheme. ${ }^{\mathrm{vi}}$ Any serious decolonising approach to Australian criminal law might legitimately characterise access to a CNS as a recent addition to fair trial rights for Aboriginal people. The recent proposed changes to the CNS, however, will reduce access to legal services and thereby the exercise of legal rights, such as the right to silence and privilege against self-incrimination by Aboriginal people in custody. Apparently, the significance of a CNS has been lost on the Federal Government in its latest attempt to translate the scheme into federal law in 2017, endangering the lives of Aboriginal people and jeopardising their access to fair trial rights and in custody. 


\section{Amendments to the Crimes Act 1914 (Cth)}

In March 2017 the Federal Government introduced a bill to amend the Crimes Act 1914 (Cth). vii The bill is designed to restore a CNS between the Australian Federal Police and ALAOs, following a finding by the ACT Supreme Court in $R v C K$ [2013] ACTSC 251. The Court found that existing custody protections for indigenous people under section $23 \mathrm{H}(1)$ of the Crimes Act $1914($ Cth $)$ ) did not require an investigating official to notify an ALAO that an Aboriginal person has been detained in police custody, prior to commencing questioning. The proposed Federal legislation amends section $23 \mathrm{H}(1)$ to require that police notify an ALAO when an Aboriginal person is taken into police custody. On its face, the new section reflects an attempt by the federal Government to implement recommendations 108, 223 and 224 of the RCIADIC in 1991, designed to reduce deaths in custody through oversight of police custody practices by ALAOs and the legal profession. For instance, Recommendation 223 contemplated that Police and Aboriginal Legal Services need to agree on a protocol about procedures and rules governing interaction between police and Aboriginal people, particularly involving 'notification of the Aboriginal Legal Service when Aboriginal people are arrested and detained'. Recommendation 224 further specified that 'appropriate steps be taken to make it mandatory for Aboriginal Legal Services to be notified upon the arrest or detention of any Aboriginal person'. viii New section $23 \mathrm{H}(1)$ however, is subject to a broad range of exceptions to the idea of mandatory notification and appears to ignore Aboriginal stakeholders, rather than reach agreement with them, in the formulation of procedural rules.'. The section has been designed mostly in consultation with the Australian Federal Police (AFP) and reflects the institutional interests of that organisation, affording significant discretion to police over a decision to notify an ALAO that an Aboriginal person has been detained in custody. 
The amending legislation retains notorious section $23 \mathrm{H}(8)$ of the Act. This section excuses Police from contacting an Aboriginal legal assistance organisation at all, if they form the discretionary opinion that the Aboriginal person is 'not at a disadvantage' during the interview process due to their 'level of education and understanding' compared 'with members of the Australian community generally'. In all other cases, the amended legislation provides that police need only ensure that 'reasonable steps' have been taken to contact an Aboriginal legal assistance organisation: section $23 \mathrm{H}(1)$ ). That is, police are not actually required to give an Aboriginal person in custody the chance to talk to a lawyer or prisoner's friend. As the bill's Explanatory Memorandum makes clear, police may take 'reasonable steps', simply by making a phone call to an ALAO and leaving a message on the organisation's answering service. ${ }^{\text {ix }}$ Provided that police wait two hours from the time of the phone call, section $23 \mathrm{H}(1)$ permits them to interview the Aboriginal person in custody who has not yet received legal advice.

This scenario, involving police leaving a message with an ALAO before interviewing an Aboriginal person in custody, was specifically contemplated by the New South Wales Supreme Court in In Campbell and 4 Ors v Director of Public Prosecutions (NSW) [2008] NSWSC 1284. In this case, Justice Hidden found that it imposed an unacceptable burden on the procedural and fair trial rights of Aboriginal people. ${ }^{\mathrm{x}}$ Clearly, there are situations in which Police are unable to make telephone contact an ALAO within two hours of detaining an Aboriginal person. This sometimes happens because arrest occurs outside working hours and a lawyer is not available via the CNS. Missed CNS phone calls are often due to poor phone reception, particularly in rural and regional areas. Alternatively, police failure to contact an ALAO may simply result from an on-call lawyer sleeping through a late-night phone call. ${ }^{\mathrm{xi}}$ 
Custody notification services are not funded in the same on-call manner as the emergency services. Neither has the Federal Government proposed increasing funding to ALAOs so that they might extend existing custody notification services. To be clear, the 'reasonable steps' provision means that Aboriginal people in custody could be deprived of access to the CNS and legal advice at the discretion of police. Allowing police simply to leave an answering message with an ALAO, as contemplated by this new legislation, means that fewer Aboriginal people will speak directly with a lawyer or prisoner's friend while in custody.

Curtailing legal advice about the right to silence may in fact generate more deaths in custody. By diminishing the privilege against self-incrimination, it is almost certain that more Aboriginal people in custody will incriminate themselves. Self-incrimination provides evidence that strengthens a prosecution case. ${ }^{\text {xii }}$ In turn, the strength of a prosecution case is often a decisive factor in a court's decision to refuse bail. ${ }^{\text {xiii }}$ By curtailing the privilege against self-incrimination, Aboriginal people will be detained longer and more often in police custody. These legislative consequences appear to contradict the key finding of the RCIADIC: that Aboriginal deaths in custody happen because 'too many Aboriginal people are taken into custody too often'. xiv

Given the limited field operations of the AFP, however, this legislation is unlikely to affect a great number of Aboriginal people at the coalface of arrest and custody procedure. Perhaps more concerning, is that the status of the federal Crimes Act 1914 as a 'model' for the States and Territories means that the proposed laws might be followed by state and territory legislatures as a 'best practice' guide. In 1994, this status was recognised by a unanimous 
commitment to its adoption by all State and Territory Premiers. ${ }^{\mathrm{xv}}$ Its ongoing significance for the States and Territories is also highlighted by the way in which it has been used by the High Court to resolve ambiguities in State law. ${ }^{\mathrm{xvi}}$ But the Commonwealth legislation is markedly weaker than other CNS schemes, notably that in NSW. As explored below, NSW currently has a best practice model that attempts to account for the needs of Aboriginal people, rather than simply those of police.

\section{NSW Custody Notification Service}

While less than perfect, the New South Wales Custody Notification Service (NSWCNS) is an improvement on the latest federal model for custody notification. The NSW scheme exists partly through legislation (embedded within the Law Enforcement Powers and Responsibilities Regulations 2016 (NSW), section 37, (LEPRR); previously, LEPRR 2002, section 33) and partly through common law. Section 37 provides that whenever an Aboriginal person is detained in custody, a 'custody manager must ... notify ... a representative of ... [the NSW ALS]...that the person is being detained in respect of an offence, and of the place at which the person in being detained'. Such an approach is significantly more onerous on police than the proposed Commonwealth legislation, requiring police merely to take 'reasonable steps to notify an ALAO' and, if unable to make contact with a lawyer, to wait two hours before questioning the person. The NSW legislation is silent in respect to the time that must elapse before police can interview an Aboriginal person in custody after attempting to contact an ALAO. Unlike the new federal legislation, which affords police discretion over this decision through the 'reasonable steps' clause, in NSW this decision has been prescribed by common law. In Campbell and 4 Ors (referred to above) the NSW Supreme Court found that if police cannot comply with custody notification provisions, they must defer any interview until such 
time as a lawyer from an ALAO can be contacted. In this case, confessional evidence was rendered inadmissible by a failure of police to comply with this requirement. And, in the intervening period between being arrested, charged and interviewed, the Court recommended that the appellants in this case should not have been taken into custody (even when faced with multiple serious offences). Rather, it was incumbent upon police to either grant bail or, if charged with a serious offence, detain the person in custody (at [18]-[20]).

The NSWCNS has been overwhelmingly successful in achieving the objective of reducing Aboriginal deaths in police custody. While NSW has had one of the highest per capita rates of Aboriginal people in police custody (compared with other Australian states and territories), it now has one of the lowest rates of Aboriginal deaths in custody. ${ }^{\text {xvii }}$ Unlike NSW, these other jurisdictions have not implemented the strongest possible CNS schemes and continue to see multiple deaths in custody every year (as discussed above). It should be noted, however, that neither the proposed federal scheme, nor the existing NSW model, require police to notify an Aboriginal legal organisation when an Aboriginal person is taken into protective police custody (usually for an alcohol or mental health related reason). Both CNS schemes could be improved by extending legislative provisions to ensure that Aboriginal legal organisations are informed whenever an Aboriginal person is in police custody for protective reasons. Such improvement also requires greater funding to ALAOs to ensure adequate staffing and monitoring of an extended CNS service.

\section{Perspectives from ALAOs}

In a Senate Inquiry into the proposed legislation, the Federal Government was advised by the author, as well as a range of Aboriginal Legal Assistance Organisations (ALAOs), about the 
problems inherent within its proposed legislation. ${ }^{\text {xviii }}$ In alerting the Federal Government to the pitfalls within its new CNS legislation, the author worked closely with a number of ALAOs, including the NSW/ACT Aboriginal Legal Service (ALS) and the North Australian Aboriginal Justice Agency (NAAJA). These organisations, together with the Western Australian Aboriginal Legal Service (WAALS), opposed the discretion that this legislation affords to police over the custody notification process. These recommendations were well received by Australian Labor Party and Greens Senators, who resolved to oppose aspects of the bill discussed by the author's submissions. Nevertheless, the Government remains unmoved by these warnings and, at the time writing, intends to pass the legislation unamended.. Given that the existing law regarding the federal CNS is unsatisfactory to both sides of politics, there is no doubt that these laws will change. The issue is what form they will take.

Perhaps the strongest perspective on the CNS, expressed by NAAJA, is that Aboriginal people must be given a complete and unassailable right to legal representation whenever they enter police custody. ${ }^{\mathrm{xix}}$ This represents an uncomplicated approach to what has become a complex custody process that poses severe consequences for Aboriginal people if not properly followed. In submissions to the Senate Inquiry, other ALAOs maintained their longstanding objection to existing section $23 \mathrm{H}(8)$ of the Act, that this provision is inherently subjective and dependent upon a highly discretionary assessment of Aboriginal people by individual officers. ${ }^{\mathrm{xx}}$ As the ALS made clear, criteria used by police to assess whether to notify an ALAO are likely to vary greatly between officers. This presents practical difficulties and may render the assessment of individual officers the subject of legal challenge. Such a provision does not exist under NSW procedural law. The ALS further suggested a credible alternative to the 'reasonable steps' measures in section $23 \mathrm{H}(1)$ : that where Police are unable to contact a representative of a local ALAO, they should attempt to contact a similar organisation within another locality or 
jurisdiction. ${ }^{\mathrm{xxi}}$ It is noted that such a suggestion might be also adopted as part of internal police policy. In this context, it would have the effect of upholding best practice and discharging police of controversial policing practice, thereby minimising legal disputation.

The proposals have largely been brushed aside by the Federal Government with the final report of the Senate Inquiry recommending that:

the Explanatory Memorandum (accompanying the Act) be updated to include a more extensive explanation of 'reasonable steps' in section $23 \mathrm{H}(1)$ of the Crimes Act 1914, including further examples of what taking 'reasonable steps' may entail in practice. ${ }^{\text {xii }}$

In other words, police will be provided with even more examples of when they may exercise their discretion to refuse legal assistance to Aboriginal people in custody. There is no suggestion to amend the current suggested practice of taking 'reasonable steps', which involves leaving a message on the answering service of an ALAO, and the report recommends passing the existing bill without amendment. ${ }^{\text {xiii }}$ Notwithstanding these recommendations, ALP and Greens Senators have used the report to document extensive objections to the legislation, citing the concerns of the author and the ALAOs mentioned here. ${ }^{\text {xxiv }}$

\section{Conclusion}

In attempting to reinstate a federal CNS, the proposed laws provide a sub-optimal 'model' scheme. Such a system stands to reduce the procedural and fair trial rights of Aboriginal people, below the level at which these rights are protected in other jurisdictions, such as New South Wales. The planned legislation disadvantages Aboriginal people in four significant ways by: 
- $\quad$ potentially increasing numbers of Aboriginal deaths in custody;

- $\quad$ compromising access to legal advice;

- $\quad$ curtailing the right to silence and privilege against self-incrimination;

- $\quad$ adding to the overrepresentation of Aboriginal people in prison;

Nevertheless, there are a number of relatively uncontroversial legislative solutions to these problems, some of which exist in other Australian jurisdictions. These include:

- $\quad$ requiring police to notify an Aboriginal legal assistance organisation as soon as an Aboriginal person is taken into custody (including protective custody and in circumstances where an Aboriginal person has waived their right to legal representation);

- $\quad$ prohibiting police from interviewing an Aboriginal person in custody until such time as a legal practitioner or representative of a local Aboriginal legal assistance organisation can be contacted and has spoken to the person in custody (unless the person in custody waives their right to legal representation);

- $\quad$ requiring police to contact an Aboriginal legal assistance organisation within another locality or jurisdiction, in the event that they are unable to contact a representative of a local Aboriginal legal assistance organisation; and

- $\quad$ deleting section $23 \mathrm{H}(8)$ of the Crimes Act 1914 in which police are not required to contact an ALAO if they form a belief that an Aboriginal person is not at a disadvantage due to their level of educational and understanding. ${ }^{\mathrm{xxv}}$

The federal Government has been put on notice of these problems and potential remedies. Meanwhile, a large gap in federal procedural law remains unfilled and continues to jeopardise the lives of Aboriginal people in police custody. Clearly, this is a matter requiring urgent legislative attention, but not in the current form proposed by the Federal Government. 


\section{References}

${ }^{\mathrm{i}}$ NITV News, The Royal Commission into Aboriginal Deaths in Custody: timeline of events and aftermath (September 2013) <http://www.sbs.com.au/nitv/article/2016/04/14/royalcommission-aboriginal-deaths-custody-timeline $>$.

ii David Biles, 'Preliminary Analysis of Current Data Base' in David Biles and David McDonald (eds), Deaths in Custody in Australia, 1980-1989 (Australian Institute of Criminology, 1992) 1-13, 2.

iii Wendy Amigo, 'Uncorroborated Confessions: Recent decisions in the NSW Court of Criminal Appeal', (1980) 3 UNSW Law Journal 3, 321.

${ }^{\text {iv }} R v$ Anunga (1976) 11 ALR 412.

${ }^{\mathrm{v}}$ LEPRR, ss. 28-38.

vi Jonathon Hunyor, Northern Territory Duty Lawyer Handbook (NAAJA, 2012).

vii Crimes Legislation Amendment (Powers, Offences and Other Measures) Bill 2017 (Cth).

viii Commonwealth, Royal Commission into Aboriginal Deaths in Custody, National Report (1991) Vol 5.

ix (Schedule 2, Item 5, (1AB)(b); and Explanatory Memorandum, Crimes Legislation

Amendment (Powers, Offences and Other Measures) Bill 2017 (Cth), 28.

${ }^{x}$ Campbell and 4 Ors $v$ Director of Public Prosecutions (NSW) [2008] NSWSC 1284 (3

December 2008).

${ }^{\mathrm{xi}}$ NSWCCL, Submission to the Senate Committee Inquiry into the Crimes Legislation Amendment Bill (2017) 4.

xii Jeremy Gans, 'DNA, Surveillance and Self-Incrimination', (2001) 13(2) Current Issues in Criminal Justice 168, 177.

xiii See, for instance, Bail Act 2013 (NSW), section 18(1)(c); and Alexopoulos v R

(Unreported, VSC, 23/2/98, BC9800603/MC 15/98).

${ }^{x i v}$ Royal Commission into Aboriginal Deaths in Custody, National Report, Vol 1, (AGPS, 1991) 1.3.1 - 1.3.3.

${ }^{x v}$ Matthew Goode, 'The Model Criminal Code Project' (1997) 5(4) Australian Law

Librarian, 265.

xvi See, for instance, Kirby J in $R v$ Barlow (1997) 144 ALR 317, at 339-341; and Charlie $v$

The Queen (1999) 162 ALR 463 (HC), Callinan J at 479[69].

xvii Eugene Schofield-Georgeson, 'NSW Ditches Another Protection for Indigenous People in

Custody', The Conversation, 10 June $2015<$ https://theconversation.com/nsw-ditches-

another-protection-for-indigenous-people-in-custody-42811> ; see also, Eugene Schofield-

Georgeson, 'Over-Incarceration', JustJustice, (Croakey, 2016) 51-54.

xviii The author drafted submissions to the Senate Inquiry on behalf of the NSWCCL (referred to above).

${ }^{x i x}$ Conversation with David Woodroofe, Principal Legal Officer at NAAJA on 9 June 2017.

${ }^{\mathrm{xx}}$ ALS, Submission to the Senate Committee Inquiry into the Crimes Legislation Amendment Bill (2017), 2; Aboriginal Legal Service of Western Australia, Submission to the Senate Committee Inquiry into the Crimes Legislation Amendment Bill (2017), 3.

${ }^{x \times i}$ ALS Submissions, above n xvii.

xxii Senate Legal and Constitutional Affairs Legislation Committee, Crimes Legislation Amendment (Powers, Offences and Other Measures) Bill 2017 [Provisions] (2017), vii. 
xxiii Ibid.

xxiv Ibid, 31-39.

${ }^{\mathrm{xxv}}$ The author suggested as much in the NSWCCL Submissions (referred to above). 